\title{
Expression of estrogen receptor alpha with a Tet-off adenoviral system induces G0/G1 cell cycle arrest in $\mathrm{SKBr} 3$ breast cancer cells
}

\author{
JING PENG and V. CRAIG JORDAN ${ }^{1}$ \\ Fox Chase Cancer Center, 333 Cottman Avenue, Philadelphia, PA 19111, USA
}

Received August 27, 2009; Accepted October 6, 2009

DOI: 10.3892/ijo_00000519

\begin{abstract}
Endocrine therapies targeting estrogen action are pivotal for the prevention and treatment of ER-positive breast cancers. Previous studies sought to recreate hormone responsiveness by the stable expression of ER $\alpha$ in the ER-negative MDA-MB-231 breast cancer cells. Paradoxically, estrogen inhibits breast cancer cell growth when an exogenous ER $\alpha$ is expressed. In this study, we have built on previous studies by developing a Tet-off adenoviral system to express ER $\alpha$ in the ER-negative SKBr3 breast cancer cells that over-express both EGFR and HER2. This system efficiently delivers ER $\alpha$ and the expression level of ER $\alpha$ is controlled by doxycycline in a concentration-dependent manner. The growth of SKBr3 was inhibited by $\mathrm{ER} \alpha$ expression and further inhibited in the presence of $1 \mathrm{nM} 17 ß$-estradiol. SKBr3 cells were arrested at G0/G1 cell cycle upon ER $\alpha$ expression, which corresponded to an increase of $\mathrm{p} 21^{\text {Cip } 1 / \text { Waf1 }}$, hypo-phosphorylation of $\mathrm{pRb}$ and decrease of E2F1. Estrogen also reduced EGFR and HER2 expression in SKBr3 cells after ER $\alpha$ was expressed. Given that estrogen-induced increase of p21 $1^{\text {Cip } 1 / \text { Waf } 1}$ and decrease of E2F1 was also observed in MDA-MB-231 cells stably transfected with ER $\alpha$, our results suggest that a common pathway might be shared by different breast cancer cell lines whose growth is suppressed by ectopic ER $\alpha$ and estrogen.
\end{abstract}

\section{Introduction}

Antihormone agents such as tamoxifen and aromatase inhibitors have been widely used to treat estrogen receptorpositive (ER-positive) breast tumors whose growth depends

Correspondence to: Dr V. Craig Jordan, ${ }^{1}$ Present address: Department of Oncology, Lombardi Comprehensive Cancer Center, Georgetown University Medical Center, 3970 Reservoir Rd NW, Washington, DC 20057, USA

E-mail:vcj2@georgetown.edu

Key words: ER-negative breast cancer, estrogen receptor, growth factor receptor, Tet-off adenoviral system, SKBr3 cells on estrogen (1). However, acquired drug resistance develops as a consequence of long-term antihormone treatment. Interestingly, estrogen exerts apoptotic actions on long-term ( $>5$ years) tamoxifen-resistant breast tumors (2) or long-term ( $>1$ year) estrogen-deprived breast cancer cells (aromatase inhibitor-resistant) (3-5). In addition, the long-term tamoxifenresistant MCF-7 breast cancer xenografts on ovariectomized athymic mice regrow and become tamoxifen-responsive again after short exposure to physiological estrogen (6). These discoveries suggest a novel strategy to kill antihormoneresistant breast cancer cells with low dose estrogen for short period and re-sensitize the tumors for further antihormone therapy. Phase II clinical trial is now ongoing to treat patients with 12-week course of low-dose estrogen after exhaustive antihormone therapy (7). It seems that estrogen induces apoptosis through different mechanisms in different breast cancer cell models. In one model, estrogen kills LTED breast cancer cells by activating the Fas/FasL signaling pathway (3). However, in another model, estrogen induces apoptosis in MCF-7:5C cells predominantly through a mitochondrial mechanism (5).

Although the development of antihormone therapies is improving cancer care for ER-positive patients, these endocrine therapies are ineffective for the treatment of ER-negative tumors that comprise about $30 \%$ of breast cancers. Therefore, it is of value to understand whether the re-introducing of ER expression into ER-negative breast cancer cells that are absolutely antihormone-resistant can modulate responsiveness to endocrine therapies. Multiple approaches are being tested in the laboratory on cultured cell lines and animal models to examine if ER-positive phenotypes can be re-created. Epigenetic methods using DNA methyltransferase (DNMT) inhibitors and/or histone deacetylase (HDAC) inhibitors have been shown to restore ER $\alpha$ expression in ER-negative breast cancer cells, whose growth is then inhibited by antiestrogens (reviewed in ref. 8). Estrogen blocks the growth inhibitory effects of antiestrogen on these cells when ER is restored using the epigenetic methods (9). Additionally, the study of estrogen and antiestrogen action has been described when ectopic ER is expressed in ER-negative cells. One way is to stably transfect ER-negative cells with plasmids encoding ER $\alpha$. Surprisingly, estrogen treatment leads to growth inhibition rather than stimulation in ER-negative Chinese hamster ovary (CHO) cells and MDA-MB-231 breast cancer cells transfected with a wild-type ER $\alpha$ cDNA $(10,11)$. The estrogen-mediated 
growth inhibition of MDA-MB-231 cells stably transfected with ER $\alpha$ seems to require regulation of E2F1 (12). Stable transfection normally takes months for a colony to be selected and expanded, and a more efficient adenoviral system was developed to express ER $\alpha$ (13). The growth of MDA-MB-231 cells that express ER $\alpha$ delivered by the adenoviral system is also suppressed by estradiol (14).

Antihormone-resistance is often linked with excessive growth factor signaling that has elevated ErbB family cell membrane receptor tyrosin kinases such as EGFR (ErbB-1) and HER2/c-neu (ErbB-2) (15). Most studies to express ectopic ER $\alpha$ have used MDA-MB-231 cells that over-express EGFR. It is important to examine how ER-negative breast cancers cells with high HER2 react to estrogen when an exogenous ER $\alpha$ is expressed. Potential new drug targets could be identified in ER-negative cancers if estrogen triggers apoptosis or growth inhibition through a common mechanism shared by different types of ER-negative cancer cells when an exogenous ER $\alpha$ is introduced. In this study, a Tet-off adenoviral system was developed to deliver ER $\alpha$ to ER-negative breast cancer SKBr3 cells that over-express both EGFR and HER2. The Tet-off adenoviral system is highly efficient and the expression level of ER $\alpha$ is controlled by addition of doxycycline in a concentration-dependent manner. Using this system, we examined the function of ER $\alpha$ and estradiol on cell proliferation. The results suggest that estrogen suppresses the proliferation of SKBr3 cells through a similar mechanism as estrogen does in MDA-MB-231 cells when an ectopic $\mathrm{ER} \alpha$ is expressed. The mechanism involves upregulation of $\mathrm{p} 21^{\text {Cip1/Waf1 }}$ and down-regulation of E2F1. The effect of estrogen on growth receptor expression was also examined in $\mathrm{SKBr} 3$ cells when exogenous ER $\alpha$ was expressed.

\section{Materials and methods}

Cells and culture conditions. SKBr3 and MDA-MB-231 cells were obtained from American Type Culture Collection (ATCC, Manassas, VA). MCF-7 cells were from Dr Dean Edwards (University of Texas, San Antonio). MCF-7/F cells were derived from MCF-7 as described (16). SKBr3, MCF-7, and $\mathrm{MCF}-7 / \mathrm{F}$ cells were maintained in full serum RPMI1640 medium supplemented with $10 \%$ fetal bovine serum (FBS), $2 \mathrm{mM}$ L-glutamine, $100 \mathrm{U} / \mathrm{ml}$ penicillin, $100 \mu \mathrm{g} / \mathrm{ml}$ streptomycin, 1X essential amino acid (all from Invitrogen, Carlsbad, CA) and $6 \mathrm{ng} / \mathrm{ml}$ bovine insulin (Sigma-Aldrich, St. Louis, MO). MDA-MB-231 cells were maintained in minimal essential medium supplemented with $5 \%$ calf serum and other supplements as the RPMI-1640 complete medium. T47D:C42 cells were cloned from T47D (from ATCC) $(17,18)$ and maintained in estrogen-free RPMI medium which is phenol red-free RPMI-1640 supplemented with $10 \%$ dextrancoated charcoal-stripped fetal bovine serum (SFS) and other supplements as the full serum RPMI-1640 medium. All cells were grown at $37^{\circ} \mathrm{C}$ with $5 \% \mathrm{CO}_{2}$.

Adenoviruses and viral infection. Ad-TRE-ER $\alpha$ adenovirus was custom-generated by Vector Biolabs (Philadelphia, PA) using human type 5 adenoviral backbone with E1 and E3 regions deleted. Adeno-X Tet-off adenovirus stock was purchased from Clontech (Mountain View, CA). It was subsequently amplified with Adeno-X Maxi Purification Kit (Clontech) and the titer was measured with Adeno-X Rapid Titer Kit (Clontech), following the instructions from the manufacturer. Ad-CMV-GFP was purchased from Vector Biolabs. For viral infection, SKBr3 cells were cultured in estrogen-free RPMI medium 3 days before the infection and throughout the experiments. Each adenovirus was added to resuspended cells at $30 \mathrm{MOI}$ (multiplicity of infection), then the cells were divided equally and $1 \mu \mathrm{g} / \mathrm{ml}$ doxycycline was added to half of the cells. Subsequently, $3 \times 10^{4}$ cells/well were seeded in 24-well plates for cell proliferation assay and $1.5 \times 10^{5}$ cells/well were seeded in 6 -well plates for protein or RNA preparation. After $24 \mathrm{~h}$, the medium was replaced with fresh medium with or without $1 \mu \mathrm{g} / \mathrm{ml}$ doxycycline containing ethanol $(\mathrm{EtOH})$, fulvestrant or $17 ß$-estradiol at concentrations indicated in the figures. The compoundcontaining medium was replaced every other day until the cells were harvested.

Cell proliferation assay. Cell DNA content was determined as a measure of cell proliferation using the Fluorescent DNA Quantitation Kit (Bio-Rad, Hercules, CA), which includes 10X TEN buffer, Hoechst dye and calf thymus DNA. Briefly, the cells were washed with $1 \mathrm{X}$ phosphate-buffered saline (PBS, Invitrogen), incubated in $0.5 \mathrm{ml} 0.1 \mathrm{X}$ TEN buffer (diluted from the 10X TEN buffer) for $1 \mathrm{~h}$ at $4^{\circ} \mathrm{C}$ then sonicated for $10 \mathrm{sec}$. Hoechst dye was diluted in 10X TEN buffer to a final concentration of $25 \mu \mathrm{g} / \mathrm{ml}$, and $20 \mu \mathrm{l}$ of the diluted dye was incubated with $0.2 \mathrm{ml}$ of the cell lysate for $1 \mathrm{~h}$ at room temperature. The fluorescence was measured with a Mithras LB 940 fluorometer (Oak Ridge, TN) and the total DNA amount was calculated based on a standard curve prepared from calf thymus DNA.

Western blot analysis. Cells were washed twice with 1X PBS and lysed in RIPA buffer (Sigma-Aldrich) supplemented with Complete Protease Inhibitor Cocktail Tablets at 1 tablet $/ 10 \mathrm{ml}$ (Roche, Indianapolis, IN). The protein concentration was determined using the BCA Protein Assay Reagent (Thermo, Rockford, IL) following instructions from the manufacturer. Total protein were separated by $4-12 \%$ sodium dodecyl sulfate polyacrylamide gel electrophoresis (SDS-PAGE, Invitrogen) and electro-blotted to polyvinylidene fluoride (PVDF) membranes. The membranes were blocked for $1 \mathrm{~h}$ at room temperature in TBST buffer $(50 \mathrm{mM}$ Tris- $\mathrm{HCl}, \mathrm{pH} 7.5$, $150 \mathrm{mM} \mathrm{NaCl}, 0.1 \%$ Tween-20) containing 5\% non-fat milk then incubated overnight at $4^{\circ} \mathrm{C}$ with primary antibodies. After being washed 3 times with TBST, the membranes were incubated with horseradish peroxidase (HRP)-conjugated secondary antibodies for $2 \mathrm{~h}$ at room temperature, washed again with TBST and visualized using ECL Western Blotting Detection Reagents (GE Healthcare, Piscataway, NJ). The antibodies against EGFR (Cat\# 2232), Rb (Cat\# 9309), Rb-P(s807/811) (Cat\# 9308) and mTOR (Cat\# 2983) were purchased from Cell Signaling (Danvers, MA). Antibodies against HER2 (Ab-20) and ER $\alpha$ (Ab-15) were from Thermo Lab Vision/NeoMarkers (Fremont, CA). Antibody against B-actin (AC-15) was from Sigma-Aldrich. Antibodies against p21 (Cat\# sc-469) and E2F1 (Cat\# sc-193) were from Santa Cruz Biotechnology (Santa Cruz, CA). The HRP-conjugated 
anti-mouse or anti-rabbit secondary antibodies were from Cell Signaling.

ERE-Luciferase reporter assay. SKBr3 cells were infected and seeded in 24-well plates as described above. Twenty-four hours after infection, $0.3 \mu \mathrm{g}$ 5X ERE-firefly-luciferase reporter plasmid and $0.1 \mu \mathrm{g}$ control TA-Renilla-luciferase plasmid (19) were used to transfect each well of cells using $15 \mu \mathrm{l}$ FuGENE ${ }^{\circledR}$ HD transfection reagent (Roche) following instructions from the manufacturer. After $24 \mathrm{~h}$, the medium was replaced with fresh medium containing different compounds as indicated in the figure. Cells were harvested $48 \mathrm{~h}$ after treatment and the activities of firefly and Renilla luciferases were analyzed with Dual-Luciferase ${ }^{\circledR}$ Reporter Assay System (Promega, Madison, WI) following instructions from the manufacturer.

Real-time reverse transcription-polymerase chain reaction (RT-PCR) assay. Total RNA was isolated with RNeasy Mini Kit (Qiagen, Valencia, CA) and quantitated with spectrometer. The cDNA was prepared from $1 \mu \mathrm{g}$ RNA with the High Capacity cDNA Reverse Transcription Kit (Applied Biosystems, Foster City, CA) in a $20-\mu 1$ reaction mix assembled according to instructions from the manufacturer. The reaction mix was incubated at $25^{\circ} \mathrm{C}$ for $10 \mathrm{~min}$ and $85^{\circ} \mathrm{C}$ for $90 \mathrm{~min}$ then diluted with $200 \mu 1$ water. Two microliters of the diluted products were used for subsequent real-time PCR amplification using either Power SYBR ${ }^{\circledR}$ Green PCR Master Mix or Taqman ${ }^{\circledR}$ Universal PCR Master Mix, both from Applied Biosystems. The reactions were performed with 7900 HT Fast Real-Time PCR System (Applied Biosystems) in 384-well plates using the standard settings. The sequences of the primers are as follows: PS2-F, 5'-CATCGACGTCCCT CCAGAAGAG; PS2-R, 5'-CTCTGGGACTAATCACCGTG CTG; PR-F, 5'-CGCGCTCTACCCTGCACTC; PR-R, 5'-TGA ATCCGGCCTCAGGTAGTT; E2F1-F, 5'-CCCAACTCCCT CTACCCTTGA; E2F1-R, 5'-TCTGTCTCCCTCCCTCACT TTC; p21-F, 5'-CTGGAGACTCTCAGGGTCGAA; p21-P, 5'-6ACGGCGGCAGACCAGCATGA[BHQ1]; p21-R, 5'GGCGTTTGGAGTGGTAGAAATCT; Rb-F, 5'-CTTGCAT GGCTCTCAGATTCAC; Rb-R, 5'-AGAGGACAAGCAGA TTCAAGGTG; 36B4-F, 5'-GTGTTCGACAATGGCAGCAT; 36B4-R, 5'-GACACCCTCCAGGAAGCGA.

Cell cycle analysis. The adenovirus-infected SKBr3 cells were plated at $1 \times 10^{6}$ per $10-\mathrm{cm}$ culture dish and treated with different compounds for $48 \mathrm{~h}$. All the cells were harvested and fixed in $70 \%$ ethanol in $1 \mathrm{X}$ PBS overnight at $4^{\circ} \mathrm{C}$. The fixed cells were washed twice with $1 \mathrm{X}$ PBS and incubated with propidium iodide (PI) staining buffer (1X PBS, 0.1\% Triton X-100, $200 \mu \mathrm{g} / \mathrm{ml}$ RNase A, and $50 \mu \mathrm{g} / \mathrm{ml} \mathrm{PI)} \mathrm{for}$ $30 \mathrm{~min}$ at $37^{\circ} \mathrm{C}$. The stained cells were analyzed using FACScan flow cytometer (Becton Dickinson, San Jose, CA) and the data were analyzed using FlowJo program (Tree Star Inc., Ashland, OR).

Statistical analysis. Data were expressed as means \pm standard deviation (SD) for at least three independent repeated experiments. Statistical significance $(\mathrm{p}<0.05)$ between two groups was assessed by unpaired, one-tailed t-test.

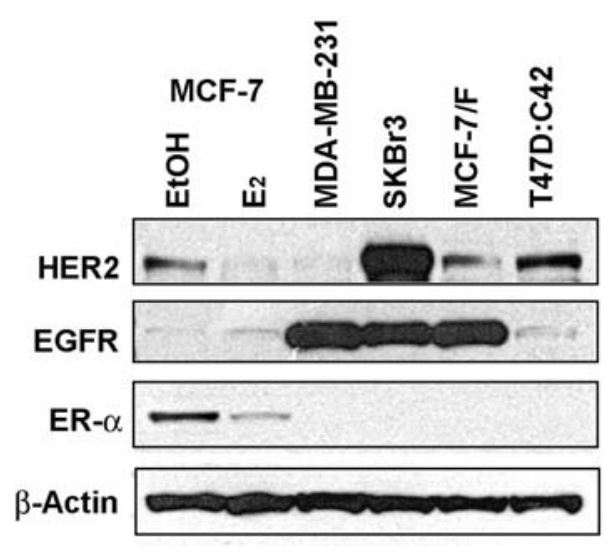

Figure 1. Comparison of HER2, EGFR and ER $\alpha$ expression between SKBr3 and other breast cancer cells. MCF-7 cells were grown in estrogen-free RPMI medium for 4 days then treated with either EtOH control or $1 \mathrm{nM} \mathrm{E}_{2}$ for 2 more days before harvest. Other cells were grown in medium as described in Materials and methods. Fifty micrograms of total proteins were used for Western blot analysis for HER2, EGFR and ER $\alpha$. The $\beta$-actin was also examined as a loading control.

\section{Results}

Expression of ERa in SKBr3 breast cancer cells with Tet-off adenoviral system. Most studies expressing ectopic ER $\alpha$ in ER-negative breast cancer cells have used MDA-MB-231 cells which have high levels of EGFR, but low levels of HER2. Since about $20 \%$ breast cancers are HER2-positive, it is important to examine if hormone-responsiveness could be restored in ER-negative breast cancer cells that over-express HER2. Therefore, we chose SKBr3 cells which over-express both HER2 and EGFR for this study. The expression of HER2, EGFR and ER $\alpha$ were compared between SKBr3 and several other breast cancer cell lines as shown in Fig. 1. The ER-positive MCF-7 cells expressed low levels of EGFR and HER2, and estrogen treatment decreased HER2 expression. MDA-MB-231 cells had high levels of EGFR but little HER2. The ER-negative MCF-7/F cells derived from MCF-7 (16) highly expressed EGFR and moderately expressed HER2. Another ER-negative T47D:C42 cells cloned from ER-positive T47D cells $(17,18)$ had moderate expression of HER2 and little expression of EGFR. Only SKBr3 cell had high levels of both HER2 and EGFR.

A Tet-off adenoviral delivery system was developed to express ER $\alpha$ in SKBr3 cells. The infection efficiency of adenoviruses in SKBr3 cells was analyzed using a green fluorescent protein (GFP) reporter adenovirus (Ad-CMV-GFP). As shown in Fig. 2A, $>95 \%$ cells were infected and expressing GFP. The adenoviral system is more efficient than plasmid transfection which normally has $<50 \%$ efficiency, thus a lengthy selection for stable-transfected cell colonies can be avoided using the adenoviral system since almost all the cells were infected and expressed the delivered gene of interest. The expression of ER $\alpha$ can be turned off by doxycycline when cells are co-infected with Adeno-X Tet-Off and AdTRE-ER $\alpha$ adenovirus simultaneously. As shown in Fig. 2B, the expression level of ER $\alpha$ decreased as the concentration of doxycycline increased from 0 to $0.8 \mathrm{ng} / \mathrm{ml}$, and ER $\alpha$ expression was almost undetectable as doxycycline concentration was 
A

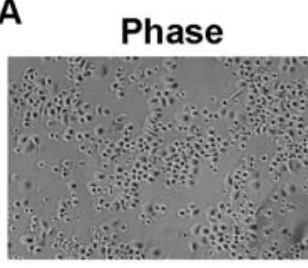

GFP

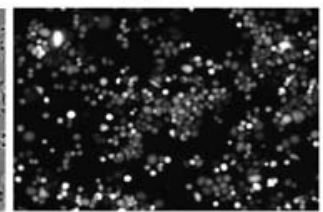

B Doxycycline (ng/ml)

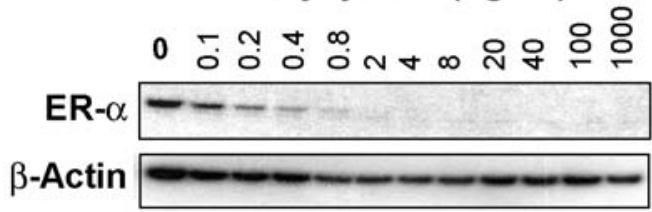

C

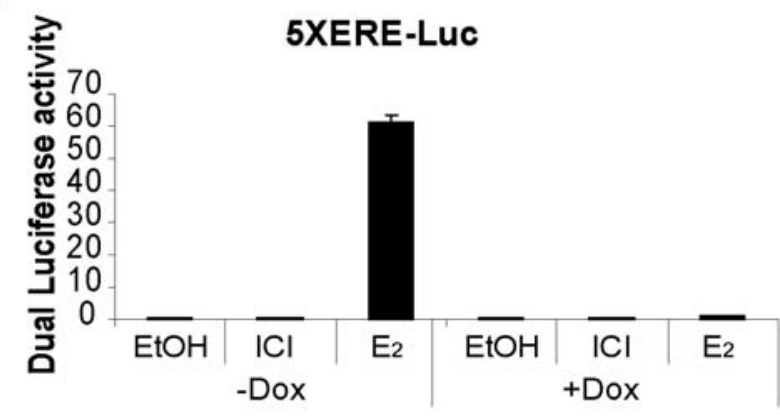

D

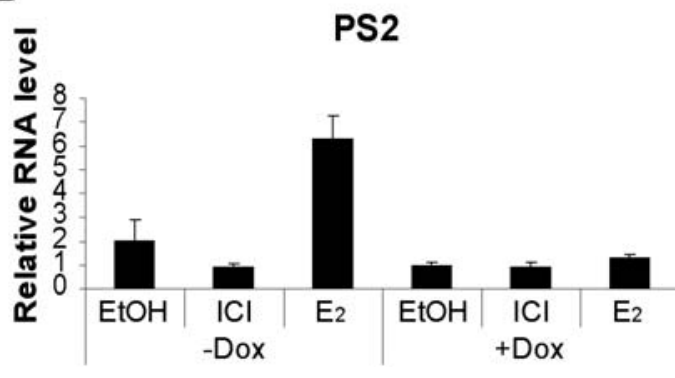

E

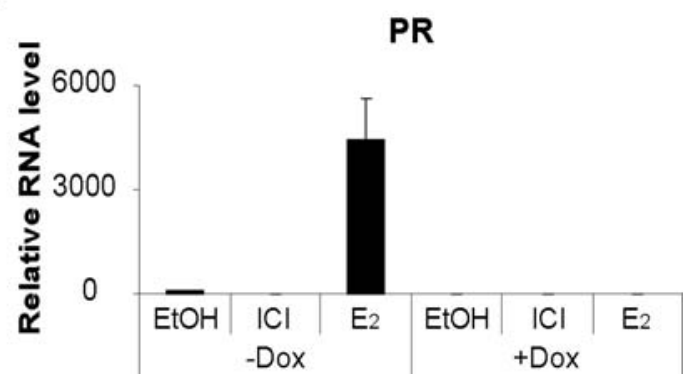

Figure 2. The Tet-off adenoviral system to express ER $\alpha$ in SKBr3 cells. (A) SKBr3 cells were infected with Ad-CMV-GFP and observed $24 \mathrm{~h}$ after infection with a TE300 fluorescence microscope (Nikon Instruments, Melville, NY). (B) SKBr3 cells were co-infected by Adeno-X Tet-off and Ad-TRE-ER $\alpha$ in the presence of doxycycline at various concentrations. The cells were harvested $48 \mathrm{~h}$ after infection and total protein was extracted for Western blot analysis (C) $\mathrm{SKBr} 3$ cells infected by Adeno-X Tet-off and Ad-TRE-ER $\alpha$ in the presence (+Dox) or absence (-Dox) of $1 \mu \mathrm{g} / \mathrm{ml}$ doxycycline were transfected with 5xEREfirefly-luciferase and TA-Renilla-luciferase plasmids. The cells were harvested for dual luciferase activity assay after 48-h treatment with the compounds as indicated. The ratio of firefly luciferase vs Renilla luciferase activities were plotted and the number of the +Dox/EtOH sample was arbitrarily set to be 1 for easy comparison. (D) SKBr3 cells infected by Adeno-X Tet-off and Ad-TRE-ER $\alpha$ in the presence (+Dox) or absence (-Dox) of $1 \mu \mathrm{g} / \mathrm{ml}$ doxycycline were treated with $0.1 \% \mathrm{EtOH}, 1 \mu \mathrm{M}$ fulvestrant (ICI) or $1 \mathrm{nM}$ 17ß-estradiol $\left(\mathrm{E}_{2}\right)$ for $48 \mathrm{~h}$. The total RNA was extracted for real-time RT-PCR analysis of PS2 or PR (E) against endogenous control 36B4 using a relative standard curve generated by 10 -fold serial dilution of MCF-7 cDNA. The value of the +Dox/EtOH sample was arbitrarily set to be 1 for easy comparison.

above $2 \mathrm{ng} / \mathrm{ml}$. The ER $\alpha$ expressed in SKBr3 cells by the adenovirus is fully functional. It activated luciferase reporter containing 5 estrogen receptor elements (5X ERE) in the presence of $1 \mathrm{nM} \mathrm{E}_{2}$ while the luciferase reporter was not detected either when ER $\alpha$ was not expressed (+Dox) or when EtOH control or pure antiestrogen fulvestrant (ICI) was added (Fig. 2C). Real-time RT-PCR assay also indicated that the exogenous $\mathrm{ER} \alpha$ induced the endogenous estrogen-responsive genes PS2 and progesterone receptor (PR) in response to $E_{2}$. The RNA level of PS2 was doubled by expression of ERa itself (compare -Dox/EtOH and +Dox/EtOH), and addition of $1 \mathrm{nM} \mathrm{E}_{2}$ further increased PS2 RNA to 6-fold (compare - Dox $/ \mathrm{E}_{2}$ and + Dox $/ \mathrm{EtOH}$ ), but addition of fulvestrant did not change PS2 RNA expression (Fig. 2D). The induction of PR RNA was more dramatic, as PR RNA was barely detectable without ER $\alpha$ expression (+Dox) or with ER $\alpha$ but in the presence of EtOH control or antiestrogen fulvestrant. However, $\mathrm{E}_{2}$ addition increased PR RNA level by thousands of folds when ER $\alpha$ was expressed (compare -Dox/ $/ \mathrm{E}_{2}$ and $+\mathrm{Dox} / \mathrm{EtOH}$, Fig. 2E).
Cell proliferation of SKBr3 cells after ERa expression. We next examined the effects of ER $\alpha$ on SKBr3 cell proliferation by measuring the total cellular DNA content. As shown in Fig. 3A, growth of SKBr3 cells was irresponsive to fulvestrant, 4-hydoxytamoxifen or $\mathrm{E}_{2}$ if no $\mathrm{ER} \alpha$ was expressed. However, expression of ER $\alpha$ itself reduced cell proliferation to about $70 \%$ (compare -Dox/EtOH and +Dox/EtOH), although the reduction was not statistically significant, similar inhibition was repeatedly observed in independent experiments. The ER $\alpha$-mediated growth suppression was abolished by fulvestrant, and addition of $1 \mathrm{nM} \mathrm{E}_{2}$ or $1 \mu \mathrm{M} 4-$ hydroxytamoxifen inhibited SKBr3 cell proliferation to about 40 and $50 \%$ respectively, which was statistically significant (compare with the + Dox/EtOH control). With the ectopic expression of $\mathrm{ER} \alpha, \mathrm{E}_{2}$ inhibited the growth of $\mathrm{SKBr} 3$ cells in a dose-dependent manner, as shown in Fig. 3B. Statistical difference was reached when $\mathrm{E}_{2}$ concentration was $\geq 10^{-10} \mathrm{M}(0.1 \mathrm{nM})$, comparing with the +Dox/EtOH control. Similar results were obtained in the time-dependent growth curve shown in Fig. 3C. 

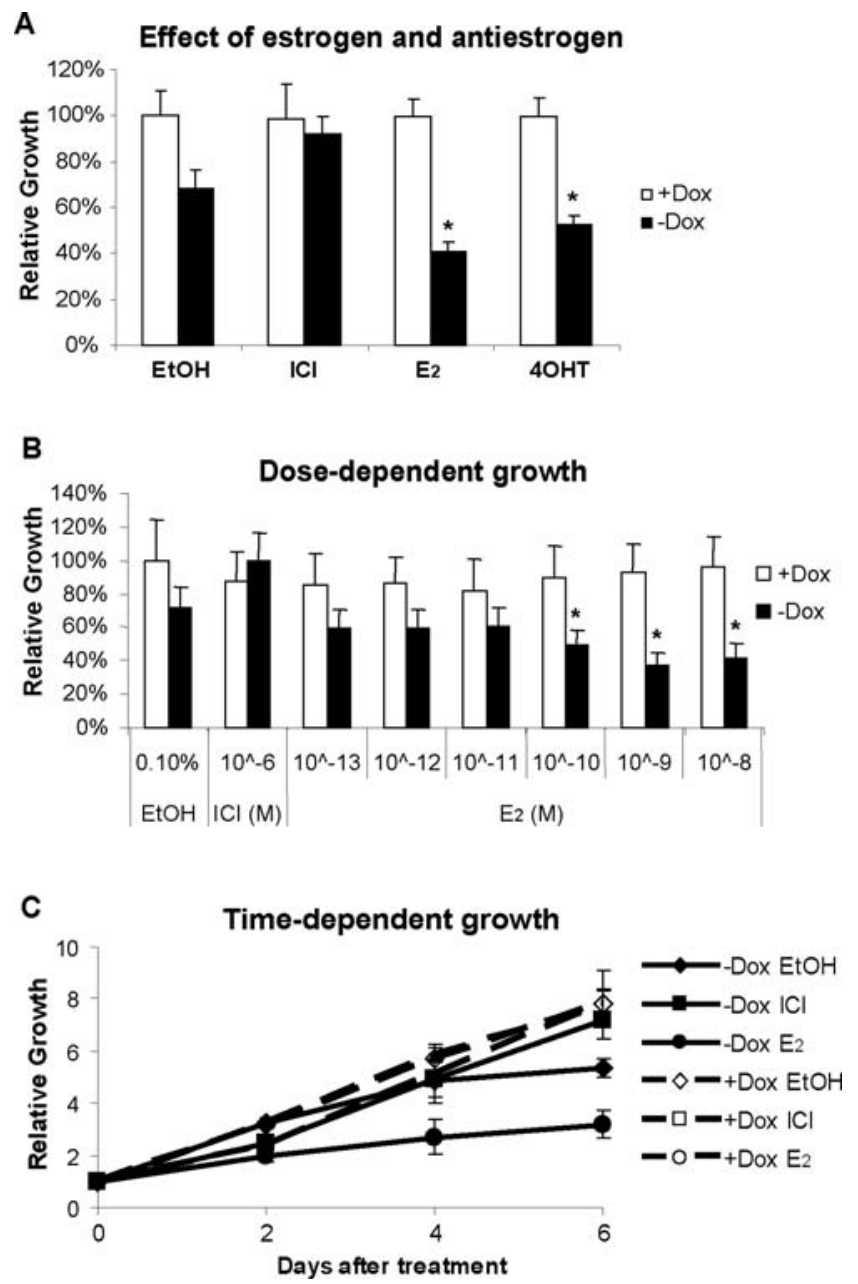

Figure 3. The effects of ER $\alpha$ expression and estrogen/antiestrogen treatment on the proliferation of $\mathrm{SKBr} 3$ cells. $\mathrm{SKBr} 3$ cells were infected by Adeno-X Tet-off and Ad-TRE-ER $\alpha$ in the presence (+Dox) or absence (-Dox) of $1 \mu \mathrm{g} / \mathrm{ml}$ doxycycline, treated by the $0.1 \% \mathrm{EtOH}(\mathrm{v} / \mathrm{v}), 1 \mu \mathrm{M}$ fulvestrant (ICI), $1 \mu \mathrm{M}$ 4-hydroxytamoxifen (4OHT) or $\mathrm{E}_{2}$ (at final concentration of $1 \mathrm{nM}$ or as indicated in the graph) and harvested for DNA quantification. (A) Growth with different ER ligands treated for 6 days. (B) Dose-dependent growth with various $\mathrm{E}_{2}$ concentrations treated for 6 days. (C) Time-dependent growth with cells harvested every 2 days after treatment. "Samples with a statistically significant difference $(\mathrm{p}<0.05$ by $\mathrm{t}$-test) from the + Dox/EtOH control.

ERa expression arrests SKBr3 cells at G0/G1 cycle. Next, flow cytometry analysis was performed to examine cell cycle progression of $\mathrm{SKBr} 3$ cells when ER $\alpha$ was expressed. As shown in Fig. 4, about 50\% cells were at G0/G1 cell cycle without $\mathrm{ER} \alpha$ (+Dox) or with $\mathrm{ER} \alpha$ but in the presence of fulvestrant (-Dox/ICI). However, the population of cells at G0/G1 cell cycle increased to about $80 \%$ when ER $\alpha$ was expressed in the presence of EtOH control or $1 \mathrm{nM} \mathrm{E}_{2}$. Apoptosis was not observed in $\mathrm{SKBr} 3$ cells as there was no significant cell accumulation at sub-G1 phase (cell debris) when ER $\alpha$ was expressed. Annexin V/PI staining, caspase activity assay or PARP-cleavage assay all confirmed that apoptosis did not occur (data not shown).

Modulation of E2F1 cell cycle checkpoint proteins by $E_{2}$ and $E R \alpha$. The transcription factor E2F1 plays an important role in $\mathrm{G} 1$ to $\mathrm{S}$ cell cycle progression. Before cells enter $\mathrm{S}$ phase, hypo-phosphorylated $\mathrm{pRb}$ protein binds to $\mathrm{E} 2 \mathrm{~F} 1$ and prevents it from activating downstream genes essential for DNA replication and cell proliferation. Activation of cyclindependent kinases (CDKs) phosphorylates $\mathrm{pRb}$ and releases E2F1 for action. CDK inhibitory proteins such as p21 Cip1/Waf1, p27 Kip1 and p16 ${ }^{\text {INK4A }}$ inhibit CDKs activity thus lead to hypophosphorylation of $\mathrm{pRb}$ and inactivation of E2F1, which in turn causes cell cycle arrest at G0/G1 phase. Stender et al (12) found that E2F1 and p21 were differentially regulated by estrogen in ER-positive MCF-7 cells and ER-stably-transfected MDA-MB-231 cells. Therefore, we also examined

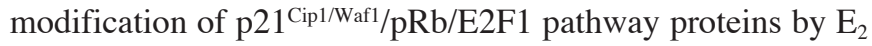
and $\mathrm{ER} \alpha$ in SKBr3 cells. As shown in Fig. 5A, p21 Cip1/Waf1 was undetectable without ER $\alpha$ expression (+Dox) or with $\mathrm{ER} \alpha$ expression but in the presence of fulvestrant. The p2 $1^{\text {Cip1/Waf1 }}$ protein level was increased by ER $\alpha$ expression and further increased by the addition of $\mathrm{E}_{2}$, which coordinated with the phosphorylation status of $\mathrm{pRb}$. Opposite regulation of E2F1 was observed by ER $\alpha$ expression and $\mathrm{E}_{2}$ treatment. The RNA levels of $\mathrm{p} 21^{\text {Cip1/Waf1 }}$ and E2F1 were regulated in a similar patten as the protein levels (Fig. 5B). A moderate down-regulation of $\mathrm{pRb}$ at protein level was also observed in ER $\alpha$-expressing samples but not at the RNA level. This might be resulted from the up-regulation of $\mathrm{p} 21^{\text {Cip } 1 / \text { Wafl }}$ because $\mathrm{p} 21^{\text {Cip } 1 / \text { Waf1 }}$ mediates $\mathrm{pRb}$ protein degradation (20).

The effects of estrogen on HER2 and EGFR expression. Intimate crosstalk between hormone receptor signaling and growth factor receptor signaling is a major contributor to breast cancer progression and endocrine resistance (15). However, an inverse correlation is often found between ER and HER2 (21,22), and estrogen down-regulates HER2 expression in ER-positive MCF-7 cells (23) (Fig. 1). Growth factor signaling is essential for $\mathrm{SKBr} 3$ cell proliferation, therefore we examined the effects of estrogen and exogenous $\mathrm{ER} \alpha$ on the expression of HER2 and EGFR. As shown in Fig. 6, ER $\alpha$ expression itself had little effect on HER2 and EGFR expression (compare -Dox/EtOH and + Dox/EtOH), however, 2-day treatment with $\mathrm{E}_{2}$ decreased EGFR protein level and 6-day treatment of $\mathrm{E}_{2}$ also reduced HER2 protein level. These results suggest that ectopic expression of ER $\alpha$ and $\mathrm{E}_{2}$ treatment might be a way to switch the more aggressive growth-factor receptor-positive tumors to the prognostically more favorable hormone-sensitive type.

\section{Discussion}

Tet-off adenoviral system is a valuable approach to deliver ectopic genes. In this study, we developed a Tet-off adenovirus to express $\mathrm{ER} \alpha$ in ER-negative $\mathrm{SKBr} 3$ cells. Adenoviruses infect the cells and deliver the gene of interest with over $95 \%$ efficiency, thus can be used to study cellular effects of the interested gene in a 'transient expression' experiment. This is not always possible using the traditional plasmid transfection with $<50 \%$ delivery efficiency because the background is high when most cells are not expressing the gene of interest. Instead, a stably-transfected clone has to be selected and expanded, which is a time-consuming process. In addition, the phenotype of a stably-transfected clone may not be the 
A

EtOH


B

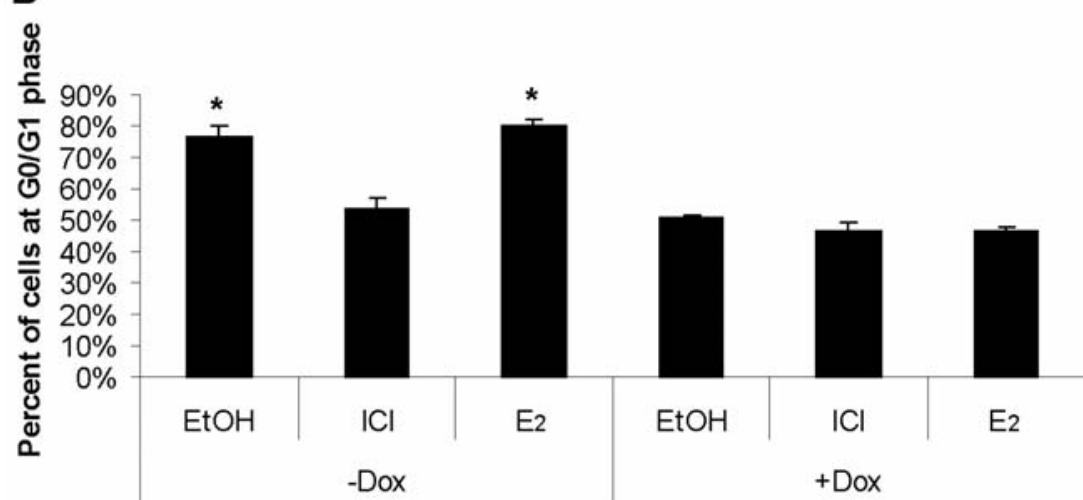

Figure 4. Cell cycle analysis of SKBr3 cells expressing ER $\alpha$. SKBr3 cells were infected by Adeno-X Tet-off and Ad-TRE-ER $\alpha$ in the presence (+Dox) or absence (-Dox) of $1 \mu \mathrm{g} / \mathrm{ml}$ doxycycline, treated by $0.1 \% \mathrm{EtOH}, 1 \mu \mathrm{M}$ fulvestrant (ICI) or $1 \mathrm{nM} \mathrm{E}_{2}$ for 2 days and harvested for cell cycle analysis. (A) Flow cytometry analysis of cell cycle distribution. (B) Percentage of cells at G0/G1 cell cycle from three independent experiments. "Samples with a statistically significant difference $(\mathrm{p}<0.05$ by $\mathrm{t}$-test) from the $+\mathrm{Dox} / \mathrm{EtOH}$ control.
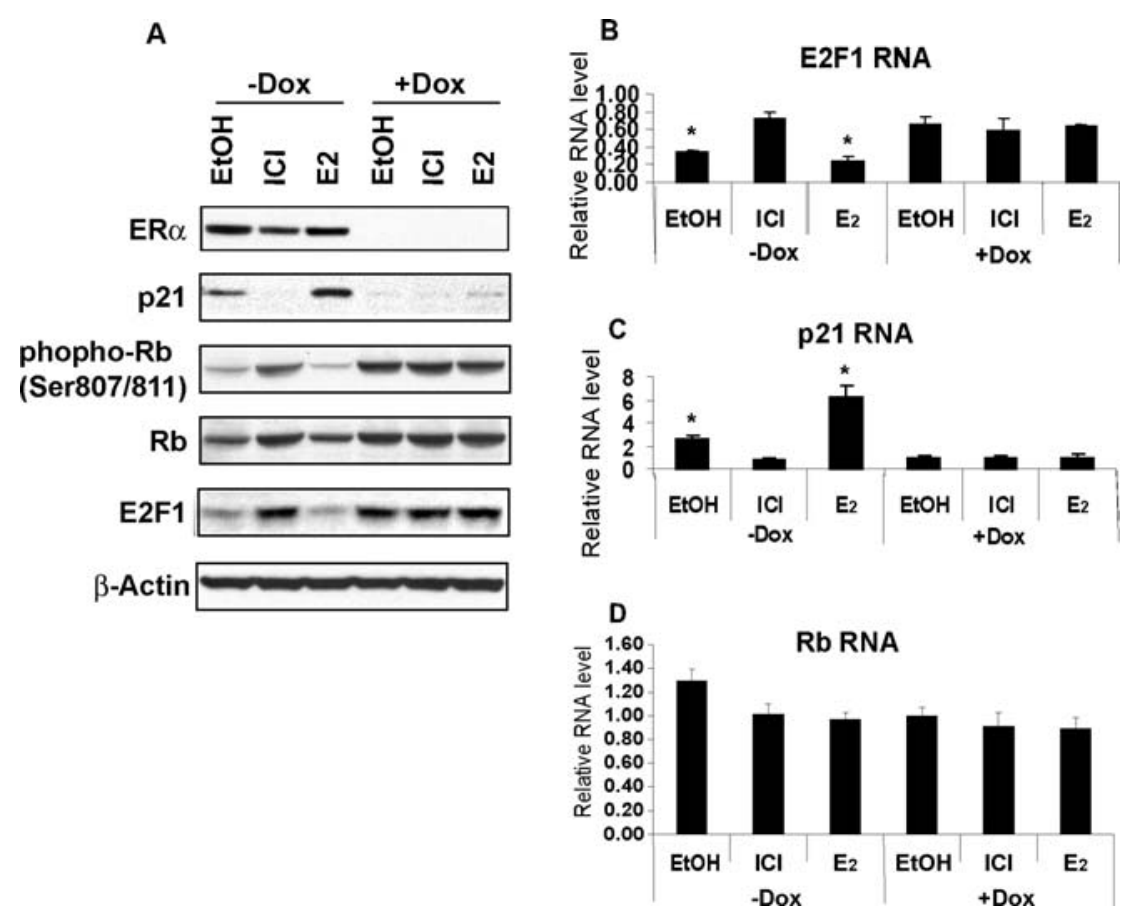

Figure 5. Modification of $\mathrm{p}^{\mathrm{Cip} 1 / \mathrm{Waf} 1}$, pRb and E2F1 by $\mathrm{ER} \alpha / \mathrm{E}_{2}$ in $\mathrm{SKBr} 3$ cells. SKBr3 cells were infected, treated and harvested as in Fig. 4. Protein was extracted for Western blot analysis (A) and RNA was prepared for real-time RT-PCR analysis to detect E2F1 (B), p21 ${ }^{\text {Cip1/Wafl }}$ (C) or pRb (D) as described in Fig. 2. "Samples with a statistically significant difference ( $<<0.05$ by t-test) from the + Dox/EtOH control. 


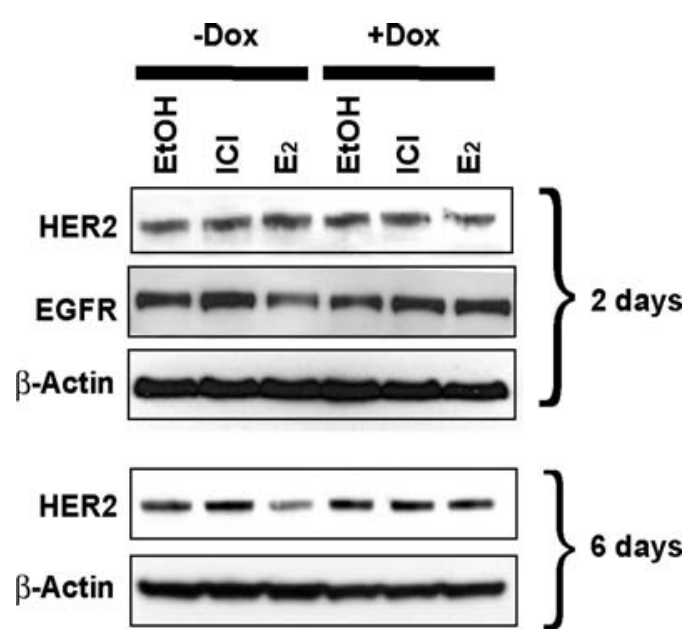

Figure 6. The effects of ER $\alpha$ expression and estrogen treatment on the expression of HER2 and EGFR in SKBr3 cells. SKBr3 cells were infected, treated for 2 days or 6 days then harvested for protein extraction and Western blot analysis.

direct result of the interested gene expression but the result of the random gene insertion at the host genome. The inability of adenoviruses to integrate into the host genome minimizes the complications of destroying or activating other host genes, thus adenoviral vector is a valuable tool to express exogenous genes for gene therapy. Adenovirus-based therapy to express p53 tumor suppressor, Advxin ${ }^{\mathrm{TM}}$ (Introgen Therapeutics, Austin, TX), has demonstrated safety profile and clinic efficacy in several tumor types and approval is being sought in Europe and the United States to treat recurrent, refractory head and neck cancer (24). Another similar adenoviral p53 transfer therapy, Gendicine ${ }^{\circledR}$ (Benda Pharmaceutical, China), has been approved to treat head and neck cancer in China (25). Therefore, adenovirus-based vectors could potentially be developed in the future to express ER $\alpha$ in ER-negative breast cancers to restore hormone responsiveness.

The Tet-off system adds another advantage to the expression method by controlling the expression level of interested gene. As shown in Fig. 2B, the amount of ER $\alpha$ expressed is regulated by doxycycline. This provides a valuable approach to study gene function in a dose-dependent manner, which is not achievable using a constitutively-expressing vector. Moreover, expression of the interested gene can be turned on or off by removal or addition of doxycycline at any time, thus studying the gene function in a timely fashion is possible.

Ectopic ERa expression and $E_{2}$ treatment arrest SKBr3 cells at G0/G1 cell cycle. In MDA-MB-231 cells, ectopic ER $\alpha$ expression by adenovirus itself had no effect on cell proliferation, but treatment of $\mathrm{E}_{2}$ suppressed cell proliferation (14). However, in SKBr3 cells, the expression of ER $\alpha$ itself inhibits cell proliferation and $\mathrm{E}_{2}$ treatment amplifies the growth inhibitory effects, while pure antiestrogen fulvestrant abolished growth inhibitory effects of ER $\alpha$ (Fig. 3). It is possible that $\mathrm{ER} \alpha$ has more ligand-independent activity in SKBr3 cells which over-express both HER2 and EGFR than in MDA-MB-231 cells that only over express EGFR. Estrogen exerts similar growth inhibitory effects on MDA-MB-231 and SKBr3 cells when ER $\alpha$ is expressed, but ER $\alpha$-expressing MDA-MB-231 and $\mathrm{SKBr} 3$ cells respond differently to tamoxifen which is ineffective in MDA-MB-231 cells (14) but inhibitory in SKBr3 cells (Fig. 3A). The mechanisms remain to be elucidated and could be that these two cell types have various cellular profile of transcription factors and different levels of nuclear receptor coregulators.

The proliferation inhibition mediated by $E R \alpha$ and $E_{2}$ in $\mathrm{SKBr} 3$ cells is likely due to cell cycle arrest at G0/G1 phase (Fig. 4), since significant apoptosis was not observed. Similar to MDA-MB-231 cells, $\mathrm{E}_{2}$ and $\mathrm{ER} \alpha$ modify the expression of $\mathrm{G} 1$ to $\mathrm{S}$ phase checkpoint proteins $\mathrm{p} 21^{\mathrm{Cip} 1 / \mathrm{Waf} 1}$ and $\mathrm{E} 2 \mathrm{~F} 1$ in $\mathrm{SKBr} 3$ cells (Fig. 5), suggesting an important role of E2F1 in hormone-mediated regulation of cell proliferation. E2F1 is critical to control cell cycle progression and apoptosis (26), and its overexpression is often linked to poor prognosis of breast cancer (27-30). Therefore, E2F1 is a potential drug target for breast cancer. In addition, $\mathrm{E}_{2}$ treatment downregulates expression of HER2 and EGFR in ER $\alpha$-expressing SKBr3 cells (Fig. 6), suggesting that growth factor signalling could be diminished by $E_{2} / E R \alpha$ and that a less aggressive hormone-responsive cancer type can be re-created.

Strategically, it is important to note that the ectopic $\mathrm{E}_{2} / \mathrm{ER} \alpha$ complex is able to block cell cycle progression at $\mathrm{G} 0 / \mathrm{G} 1$ phase. A similar effect occurs with endogenous $\mathrm{E}_{2} / \mathrm{ER} \alpha$ complex in the MCF-7:5C cell line that is resistant to estrogen withdrawal (5). However, in contrast to the MCF-7:5C cells that progress to apoptosis, $\mathrm{SKBr} 3$ cells with ectopic ER $\alpha$ do not. It will be important to discover the reason for the failure to trigger apoptosis because the ectopic ER $\alpha$ could be used to define and identify a common pathway for future drug discovery. In other words, a proportion of cancers that never had the ER may have a vestigial pathway that could be activated to provoke apoptosis. The Tet-off adenoviral ER $\alpha$ system may be an approach to discover the veracity of this drug discovery strategy.

\section{Acknowledgements}

We appreciate the assistance of Flow Cytometry and Cell Sorting Facility at the Fox Chase Cancer Center for flow cytometry analysis. Dr Jordan is supported by the Department of Defense Breast Program under award number BC050277 Center of Excellence, FCCC Core Grant NIH P30 CA006927, the Genuardi's Fund, the Weg Fund of Fox Chase Cancer Center and the Hollenbach Family Fund. The views and opinions of the author(s) do not reflect those of the US Army or the Department of Defense.

\section{References}

1. Jordan VC: A century of deciphering the control mechanisms of sex steroid action in breast and prostate cancer: the origins of targeted therapy and chemoprevention. Cancer Res 69: 1243-1254, 2009.

2. Wolf DM and Jordan VC: A laboratory model to explain the survival advantage observed in patients taking adjuvant tamoxifen therapy. Recent Results Cancer Res 127: 23-33, 1993.

3. Song RX, Mor G, Naftolin F, et al: Effect of long-term estrogen deprivation on apoptotic responses of breast cancer cells to 17beta-estradiol. J Natl Cancer Inst 93: 1714-1723, 2001. 
4. Lewis JS, Osipo C, Meeke K and Jordan VC: Estrogen-induced apoptosis in a breast cancer model resistant to long-term estrogen withdrawal. J Steroid Biochem Mol Biol 94: 131-141, 2005.

5. Lewis JS, Meeke K, Osipo C, et al: Intrinsic mechanism of estradiol-induced apoptosis in breast cancer cells resistant to estrogen deprivation. J Natl Cancer Inst 97: 1746-1759, 2005.

6. Yao K, Lee ES, Bentrem DJ, et al: Antitumor action of physiological estradiol on tamoxifen-stimulated breast tumors grown in athymic mice. Clin Cancer Res 6: 2028-2036, 2000.

7. Jordan VC: The 38th David A. Karnofsky lecture: the paradoxical actions of estrogen in breast cancer - urvival or death? J Clin Oncol 26: 3073-3082, 2008.

8. Brinkman JA and El-Ashry D: ER re-expression and resensitization to endocrine therapies in ER-negative breast cancers. J Mammary Gland Biol Neoplasia 14: 67-78, 2009.

9. Bayliss J, Hilger A, Vishnu P, Diehl K and El-Ashry D: Reversal of the estrogen receptor negative phenotype in breast cancer and restoration of antiestrogen response. Clin Cancer Res 13: 7029-7036, 2007.

10. Jiang SY and Jordan VC: Growth regulation of estrogen receptornegative breast cancer cells transfected with complementary DNAs for estrogen receptor. J Natl Cancer Inst 84: 580-591, 1992.

11. Levenson AS and Jordan VC: Transfection of human estrogen receptor (ER) cDNA into ER-negative mammalian cell lines. J Steroid Biochem Mol Biol 51: 229-239, 1994.

12. Stender JD, Frasor J, Komm B, Chang KCN, Kraus WL and Katzenellenbogen BS: Estrogen-regulated gene networks in human breast cancer cells: involvement of E2F1 in the regulation of cell proliferation. Mol Endocrinol 21: 2112-2123, 2007.

13. Lazennec G, Alcorn JL and Katzenellenbogen BS: Adenovirusmediated delivery of a dominant negative estrogen receptor gene abrogates estrogen-stimulated gene expression and breast cancer cell proliferation. Mol Endocrinol 13: 969-980, 1999.

14. Lazennec G and Katzenellenbogen BS: Expression of human estrogen receptor using an efficient adenoviral gene delivery system is able to restore hormone-dependent features to estrogen receptor-negative breast carcinoma cells. Mol Cell Endocrinol 149: 93-105, 1999.

15. Arpino G, Wiechmann L, Osborne CK and Schiff R: Crosstalk between the estrogen receptor and the HER tyrosine kinase receptor family: molecular mechanism and clinical implications for endocrine therapy resistance. Endocr Rev 29: 217-233, 2008.

16. Liu H, Cheng D, Weichel AK, et al: Cooperative effect of gefitinib and fumitremorgin c on cell growth and chemosensitivity in estrogen receptor alpha negative fulvestrantresistant MCF-7 cells. Int J Oncol 29: 1237-1246, 2006.
17. Murphy CS, Pink JJ and Jordan VC: Characterization of a receptor-negative, hormone-nonresponsive clone derived from a T47D human breast cancer cell line kept under estrogen-free conditions. Cancer Res 50: 7285-7292, 1990.

18. Pink JJ, Bilimoria MM, Assikis J and Jordan VC: Irreversible loss of the oestrogen receptor in T47D breast cancer cells following prolonged oestrogen deprivation. Br J Cancer 74: 1227-1236, 1996.

19. Ariazi EA, Kraus RJ, Farrell ML, Jordan VC and Mertz JE: Estrogen-related receptor alpha1 transcriptional activities are regulated in part via the ErbB2/HER2 signaling pathway. Mol Cancer Res 5: 71-85, 2007.

20. Broude EV, Swift ME, Vivo C, et al: p21(Waf1/Cip1/Sdi1) mediates retinoblastoma protein degradation. Oncogene 26: 6954-6958, 2007.

21. Schiff R, Massarweh SA, Shou J, et al: Advanced concepts in estrogen receptor biology and breast cancer endocrine resistance: implicated role of growth factor signaling and estrogen receptor coregulators. Cancer Chemother Pharmacol 56 (Suppl. 1): 10-20, 2005.

22. Huang HJ, Neven P, Drijkoningen M, et al: Hormone receptors do not predict the HER2/neu status in all age groups of women with an operable breast cancer. Ann Oncol 16: 1755-1761, 2005.

23. Read LD, Keith D Jr, Slamon DJ and Katzenellenbogen BS: Hormonal modulation of HER-2/neu protooncogene messenger ribonucleic acid and p185 protein expression in human breast cancer cell lines. Cancer Res 50: 3947-3951, 1990.

24. Senzer $\mathrm{N}$ and Nemunaitis $\mathrm{J}$ : A review of contusugene ladenovec (Advexin) p53 therapy. Curr Opin Mol Ther 11: 54-61, 2009.

25. Patil SD, Rhodes DG and Burgess DJ: DNA-based therapeutics and DNA delivery systems: a comprehensive review. AAPS J 7: E61-E77, 2005.

26. De Gregori J and Johnson DG: Distinct and overlapping roles for E2F family members in transcription, proliferation and apoptosis. Curr Mol Med 6: 739-748, 2006.

27. Vuaroqueaux V, Urban P, Labuhn M, et al: Low E2F1 transcript levels are a strong determinant of favorable breast cancer outcome. Breast Cancer Res 9: R33, 2007.

28. Baldini E, Camerini A, Sgambato A, et al: Cyclin A and E2F1 overexpression correlate with reduced disease-free survival in node-negative breast cancer patients. Anticancer Res 26: 4415-4421, 2006.

29. Han S, Park K, Bae BN, et al: E2F1 expression is related with the poor survival of lymph node-positive breast cancer patients treated with fluorouracil, doxorubicin and cyclophosphamide. Breast Cancer Res Treat 82: 11-16, 2003.

30. Zhang SY, Liu SC, Al-Saleem LF, et al: E2F-1: a proliferative marker of breast neoplasia. Cancer Epidemiol Biomarkers Prev 9: 395-401, 2000. 